\title{
IMPROVING OF HOT WORKABILITY AND EXPANDING THE TEMPERATURE RANGE OF SAFE HOT WORKING FOR M35 HIGH-SPEED STEEL
}

\author{
IZBOLJŠANJE VROČE PREOBLIKOVALNOSTI IN RAZŠIRITEV \\ TEMPERATURNEGA INTERVALA VARNEGA PREOBLIKOVANJA \\ V VROČEM ZA HITROREZNO JEKLO M35
}

\author{
Iztok Peruš ${ }^{1}$, Milan Terčelj ${ }^{1}$, Matjaž Godec ${ }^{2}$, Goran Kugler ${ }^{1}$ \\ ${ }^{1}$ University of Ljubljana, Faculty of Natural Science and Engineering, 12 Aškerčeva street, 1000 Ljubljana, Slovenia \\ ${ }^{2}$ Institute of Metals and Technology, Lepi pot 11, 1000 Ljubljana, Slovenia \\ goran.kugler@omm.ntf.uni.lj.si
}

Prejem rokopisa - received: 2016-07-12; sprejem za objavo - accepted for publication: 2016-08-31

doi:10.17222/mit.2016.150

\begin{abstract}
Increasing the hot workability and expanding the temperature working range for M35 high-speed steel (HSS) by industrial hot rolling as well as by hot compression tests have been studied and achieved. The types of carbides for as-cast as well as for wrought states were revealed by EBSD and the optimal soaking temperatures for both microstructural states were assessed. The soaking temperature had a decisive influence on the characteristics of carbides that lead to improving the intrinsic hot workability as well as to considerably expanding the temperature range of safe hot working down to $850{ }^{\circ} \mathrm{C}$. The apparent activation energy for hot working which amounts $639 \mathrm{~kJ} / \mathrm{mol}$ as well as constants of the hyperbolic sine constitutive equation for extended temperature range have been calculated. Industrial practice confirms the laboratory results.

Keywords: M35 HSS, hot workability, carbides, EBSD, activation energy
\end{abstract}

$\mathrm{Na}$ osnovi vročega valjanja $\mathrm{v}$ industrijskih razmerah ter s tlačnimi preizkusi v vročem smo študirali in izboljšali vročo preoblikovalnost hitroreznega orodnega jekla M35 ter razširili temperaturni interval varnega preoblikovanja. Na osnovi posebej zasnovane metodologije, smo ocenili optimalno temperaturo žarjenja pred vročim preoblikovanjem, s pomočjo EBSD, pa smo določili tipe karbidov tako za predelano, kot tudi za lito stanje obravnavanega jekla. Temperatura žarjenja pred preoblikovanjem močno vpliva na značilnosti karbidov in posledično na vročo preoblikovalnost ter temperaturni interval varnega preoblikovanja. $\mathrm{Na}$ osnovi izmerjenih krivulj tečenja so bili za razširjen temperaturni interval izračunani parametri sinus hiperbolične konstitucijske zveze ter navidezna aktivacijska za deformacijo, ki znaša $639 \mathrm{~kJ} / \mathrm{mol}$. Rezultati laboratorijskih testiranj so bili uporabljeni in potrjeni $\mathrm{v}$ industrijski praksi.

Ključne besede: hitrorezno jeklo M35, vroča preoblikovalnost, karbidi, EBSD, aktivacijska energija

\section{INTRODUCTION}

In order to increase the economy of tool-steels production, both the improvement of their intrinsic hot deformability and the extension of temperature range of safe hot working are required. An improvement of the intrinsic hot workability of tool steels is related to the characteristics of carbides ${ }^{1-4}$ that on the other hand have a large influence on the mechanical properties of tool steels that are used for the manufacture of various tools and dies usually subjected to high mechanical, temperature, chemical and tribological loads. ${ }^{5-7}$ Referring to the scientific literature, it is known that initial deformations at upper temperature limit, as well as final deformations at lower temperature limit of hot working range, are characterized by considerably decreased hot deformability in comparison to temperatures within the mentioned range. ${ }^{1-4,8-13}$ The decreased hot deformability at the upper limit is attributed to the characteristics of carbides, i.e., to their type, size, shape, size- and/or spatial- distributions, fraction, melting point of eutectic carbides and/or other phases, etc. Also at lower temperature limit charac- teristics of carbides (i.e., with additionally precipitated secondary carbides) are responsible for pore deformability, where this is related also with the effect of a decreased recrystallization rate. Moreover, the characteristics of the carbides are also influenced by the casting temperature and solidification rate. ${ }^{3,14-23}$ The appearance of cracks on areas that are most exposed during thermo-mechanical processing are thus related to similar conditions as described above for both limits of the safe hot working range. These areas are in combination with increased tensile strains additionally subjected to accelerated heating and/or cooling. ${ }^{24}$ Some recently published works ${ }^{3-4}$ reported that by proper selection of the process parameters prior to hot deformation the increase of hot deformability can be achieved.

In the present study we report about the increase of the hot workability of M35 high-speed steel (HSS) which is used for making severely stressed drills, milling cutters, formed tools, tap drills and cold forming tools, where an increased toughness is required. So far a temperature of $900{ }^{\circ} \mathrm{C}$ was considered as the lowest 


\section{PERUŠ et al.: IMPROVING OF HOT WORKABILITY AND EXPANDING THE TEMPERATURE RANGE ...}

temperature for the safe hot working of HSS. But market demands for increasing the mechanical properties as well as for lowering the dimensions of semi-products (also below $\Phi=14 \mathrm{~mm}$ ) consequently requires hot rolling at lower final temperatures down to $850{ }^{\circ} \mathrm{C}$. Therefore, the aims of our research were to: (i) study the possibility of extension of hot working range based on optimal selection of appropriate soaking temperature, (ii) to improve the microstructure of final rolled profile, (iii) to determine the main characteristics of the carbides, and (iv) to determine the activation energy for hot working considering an extended temperature range.

\section{EXPERIMENTAL PART}

The chemical composition in mass fractions $(w / \%)$ of the studied M35 HSS was: $0.92 \mathrm{C}, 0.28 \mathrm{Si}, 0.35 \mathrm{Mn}$, $4.52 \mathrm{Co}, 4.11 \mathrm{Cr}, 4.94 \mathrm{Mo}, 2,03 \mathrm{~V}, 6.35 \mathrm{~W}, 0.021 \mathrm{P}$ and $0.012 \mathrm{~S}$. Besides industrial hot rolling of ingot and billet, three types of laboratory hot compression tests for M35 HSS were conducted. For these tests cylindrical specimens with dimensions of $\Phi 10 \times 15 \mathrm{~mm}$ were cut from as-cast ingot and from a square billet, i.e., in the wrought state. The first type of (i) hot compression tests carried out on Gleeble 1500D is related to assessment of an optimal soaking temperature for as-cast and wrought initial microstructural states, respectively, using a special procedure developed by T. Večko Pirtovšek et al. ${ }^{4}$ To determine the optimal soaking temperature or upper temperature limit of safe hot-working specimens were soaked for $2 \mathrm{~h}$ at selected temperature (beginning at 1200 ${ }^{\circ} \mathrm{C}$ ) and then compressed at this temperature up to true strain of 0.9 using constant strain rate of $1 \mathrm{~s}^{-1}$. The upper safe hot-working temperature is then selected as the highest temperature where no macro cracks on the surface of the deformed specimens appeared as well as appropriate microstructure, i.e., no oversized carbides and grains, in the deformed specimen was obtained. To determine the optimal lower safe hot working temperature, samples were soaked on determined high limit and then cooled to low deformation temperature (at first to $900{ }^{\circ} \mathrm{C}$, considered appropriate in industrial practice) and compressed up to true strain of 0.9 using constant strain rate of $1 \mathrm{~s}^{-1}$. If there were no cracks on the sample surface, temperature was lowered for $10{ }^{\circ} \mathrm{C}$ and procedure repeated until cracks were noticed on the deformed surface. A safe lower hot deformation limit is then last low deformation temperature without cracks on the sample surface. Using this procedure also appropriate microstructure in compressed samples should be obtained, i.e., carbides growth during soaking should be minimal, etc. The detailed description of the procedure is given in ${ }^{4}$.

The second type of (ii) hot compression tests is similar to first type, i.e., including soaking at selected temperature (beginning at $1200{ }^{\circ} \mathrm{C}$ ), which was followed by cooling and hot compression at a selected lower temperature. In this way the influence of the soaking tempe- rature on the shifting of upper limit of temperature range of safe hot working was studied.

Furthermore, in order to study the mechanical and microstructural response on impaired deformation conditions, especially at lower temperatures, a third type (iii) of hot compression tests were carried out, i.e., compression in strain rates range $0.001-10 \mathrm{~s}^{-1}$ and temperature range $1150{ }^{\circ} \mathrm{C}$ to $850{ }^{\circ} \mathrm{C}$. During compression testing the samples were heated with a rate of $3^{\circ} \mathrm{C} / \mathrm{s}$ to the soaking temperature and holding there for $10 \mathrm{~min}$, which was then followed by cooling to the deformation temperature with $2{ }^{\circ} \mathrm{C} / \mathrm{s}$ and holding on deformation temperature for $10 \mathrm{~min}$. After deformation the samples were quenched with water. The flow curves were determined by considering the temperature compensation $^{1}$ for higher strain rates. The microstructure and the precipitation of carbides on deformed and quenched samples have been studied and the apparent activation energy for hot working for an extended temperature range was calculated.

Optical microscopy (OM, Carl Zeiss AXIO Imager. $\mathrm{A} 1 \mathrm{~m})$ and a field-emission scanning electron microscope (FE SEM JEOL 6500F) in combination with the attached energy-dispersive spectroscopy (EDS, INCA $x$-SIGHT $\mathrm{LN}_{2}$ ) and HKL Nordlys II electron backscatter diffraction (EBSD) camera using Channel5 software analytical tools were applied for observation of the microstructure and determination of the type of carbides. The SEM was operated at $15 \mathrm{kV}$ and a $1.5-\mathrm{nA}$ current for the EDS spot and map analysis as well as for EBSD spot analysis, with a tilting angle of $70^{\circ}$. Individual diffraction patterns were obtained with $4 \times 4$ binning and using 5-7 bands. For EDS analysis only 15 $\mathrm{kV}$ was used to get small analysing volume; however, it was estimated to be approximately $1 \mu \mathrm{m}^{3}$. Therefore, measuring compositions of carbides we get also information from the matrix and thus the iron amounts in the carbides are much higher as it is. Also, the carbon in carbides is increased due to carbon build up under the electron beam.

\section{RESULTS AND DISCUSSION}

\subsection{Initial microstructure}

In Figure 1a the initial as-cast microstructures with details in Figure 1b and denoted spots for EBSD analysis for M35 HSS are presented. The microstructures consist of martensite, primary, eutectic as well as secondary carbides. In Figure 2c a Kikuchi pattern for spot 2 (i.e., eutectic carbides) is given that reveals $\mathrm{M}_{2} \mathrm{C}$ $\left(\mathrm{Mo}_{2} \mathrm{C}-\right.$ Space group 60, Pbcn, Laue group $\left.3 \mathrm{mmm}\right)$ type of carbides. Similar result was obtained also for spots 1 and 4, while for spots 3 and $5 \mathrm{MC}$ (VC - Space group 225, F m-3m, Laue group $11 \mathrm{~m}-3 \mathrm{~m}$ ) type of carbides were revealed. Analysis of the distribution of Mo, $\mathrm{W}, \mathrm{V}, \mathrm{Cr}$ reveals that eutectic carbides (spots 1,2 and 4) are mainly composed of Mo (Figure 1d) as well as of W. 

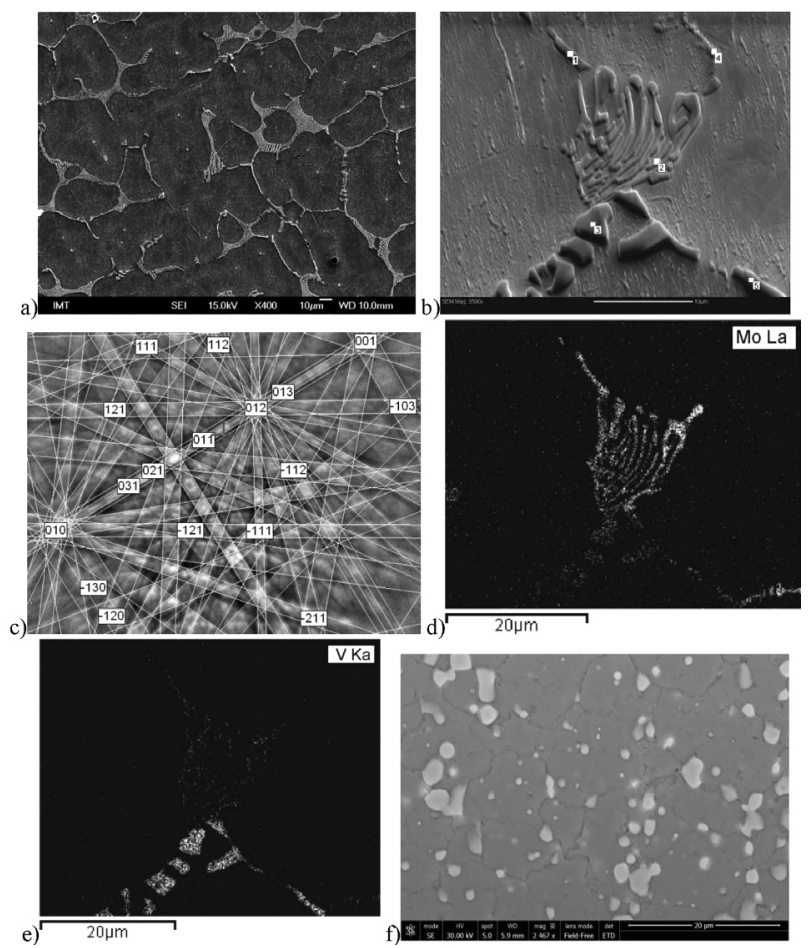

Figure 1: a) Initial microstructure of as-cast specimen from ingot with detail and b) denotes spots for EBSD and c) EDS analysis Kikuchi pattern for spot $2\left(\mathrm{M}_{2} \mathrm{C}\right.$ type of carbides), d) distribution of Mo, e) distribution of $\mathrm{V}$ and $\mathrm{f}$ ) wrought microstructure

Slika 1: a) Začetna mikrostruktura litega stanja za vzorce vzete iz ingota $\mathrm{z}$ detajlom in b) označena mesta za EBSD in c) EDS-analiza Kikuchijevih vzorcev za točko $2\left(\mathrm{M}_{2} \mathrm{C}\right.$ tip karbidov), d) porazdelitev $\mathrm{Mo}, \mathrm{e})$ porazdelitev $\mathrm{V}$ in $\mathrm{f}$ ) predelana mikrostruktura

On the other hand, the primary carbides (spots 3 and 5) are mainly composed of V (Figure 1e). Analysis of chemical composition on spots denoted in Figure $\mathbf{2 b}$ as well as type of carbides is given in Table 1. Thus eutec-
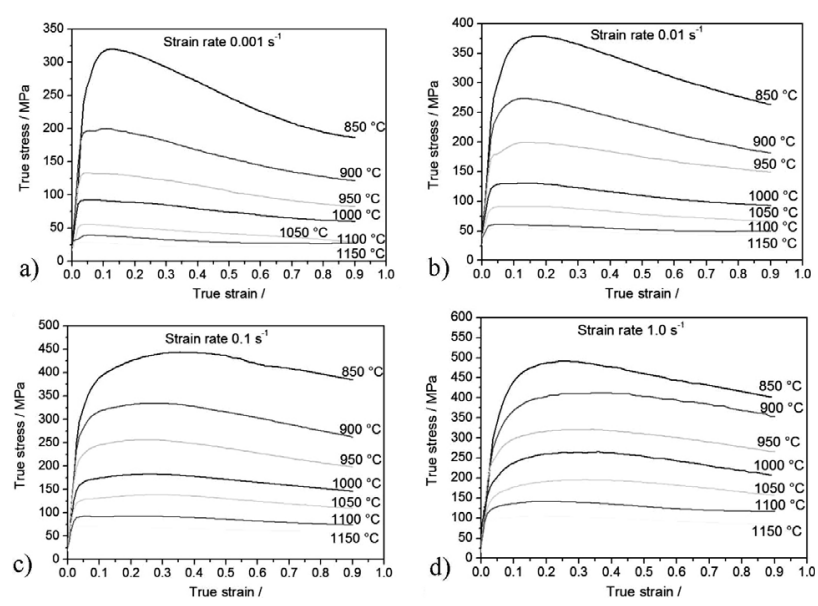

Figure 2: Flow curves for M35 HSS for temperature range 850-1150 ${ }^{\circ} \mathrm{C}$ and different strain rates: a) for strain rate of $0.001 \mathrm{~s}^{-1}$, b) for strain rate $\left.0.01 \mathrm{~s}^{-1}, \mathrm{c}\right)$ for strain rate $0.1 \mathrm{~s}^{-1}, \mathrm{~d}$ ) strain rate of $1 \mathrm{~s}^{-1}$, wrought state

Slika 2: Krivulje tečenja za hitrorezno jeklo M35 v temperaturnem območju $850-1150{ }^{\circ} \mathrm{C}$ pri različnih hitrostih deformacije: a) $0.001 \mathrm{~s}^{-1}$, b) $0.01 \mathrm{~s}^{-1}$, c) $0.1 \mathrm{~s}^{-1}$, d) $1 \mathrm{~s}^{-1}$; predelano stanje tic carbides are $\mathrm{M}_{2} \mathrm{C}$ type, while the primary carbides are of $\mathrm{MC}$ type. The wrought microstructure is given in Figure 1f. From this figure it is visible that the eutectic carbides are broken down and the size of grains is decreased in comparison to the microstructure given in Figure 1a.

Table 1: Average chemical compositions of the analysed carbides on spots denoted in Figure 1b in mass fractions, $(w / \%)$

Tabela 1: Povprečna kemijska sestava analiziranih karbidov na mestih, ki so označena na Sliki 1b, v masnih deležih, (w/\%)

\begin{tabular}{|c|c|c|c|c|c|c|c|c|}
\hline & C & V & Cr & Fe & Co & Mo & W & Type \\
\hline Spots 1,2,4 & 8.9 & 9.2 & 5.1 & 6.1 & - & 35.4 & 35.5 & $\mathrm{M}_{2} \mathrm{C}$ \\
\hline Spots 3,5 & 15.3 & 37.6 & 3.3 & 6.7 & - & 17.0 & 20.1 & $\mathrm{MC}$ \\
\hline
\end{tabular}

\subsection{Obtained optimal soaking temperatures and flow curves}

Using the procedure developed ${ }^{4}$ the optimal soaking temperatures for as-cast and for wrought states were assessed to be $1150{ }^{\circ} \mathrm{C}$ and $1160{ }^{\circ} \mathrm{C}$, respectively. This enables safe hot working within the temperature range between assessed optimal soaking temperature and 850 ${ }^{\circ} \mathrm{C}$. Our study also revealed, i.e., using the second type of hot compression tests, that by using higher soaking temperature (e.g., $1200^{\circ} \mathrm{C}$ ), at upper temperature limit of safe hot working is lower by about $20{ }^{\circ} \mathrm{C}$, while the lower temperature limit is about $50{ }^{\circ} \mathrm{C}$ higher. Furthermore, it was found that at optimal soaking temperatures determined in the present work and soaking time of $2 \mathrm{~h}$, the carbides did not exhibit extensive growth. In Figures 2a to $\mathbf{2 d}$ flow curves (i.e., the wrought state) for the temperature range $1150-850{ }^{\circ} \mathrm{C}$ and strain rate range $0.001-1.0 \mathrm{~s}^{-1}$ are given. Achieving the peak values with an increasing of the strain rate and decreasing of the temperature suggests that dynamic recrystallization has taken place during the hot deformation, which was also confirmed by the inspection of the microstructures.

The strain-rate and temperature dependences of the peak stress were determined using the hyperbolic sine Equation (1) 25 :

$$
Z=\dot{\varepsilon} \cdot \exp \left(\frac{Q}{R T}\right)=A(\sin \alpha \sigma)^{n}
$$

where $Z$ is the Zener-Hollomon parameter, $R$ is the gas constant, $Q$ is the apparent activation energy for hot working, and $A, n$ and $\alpha$ are constants. The activation energies as well as the constants in this Equation (1) were determined using the procedure developed by $\mathrm{G}$. Kugler et al. ${ }^{26}$ The values of all constants and activation energy are given Figure 3a. Thus the apparent activation energy for hot deformation amounts to 639 $\mathrm{kJ} / \mathrm{mol}$. That is slightly higher in comparison to values found in literature for other HSSs. Namely, C. A. Imbert et al. $^{2}$ obtained a value for the activation energy of 455 $\mathrm{kJ} / \mathrm{mol}$ for M2 HSS, while J. Liu et al. ${ }^{1}$ obtained values of 467 and $654 \mathrm{~kJ} / \mathrm{mol}$ for the upper and lower temperature ranges, respectively, for T1 HSS. The comparison 
I. PERUŠ et al.: IMPROVING OF HOT WORKABILITY AND EXPANDING THE TEMPERATURE RANGE ...

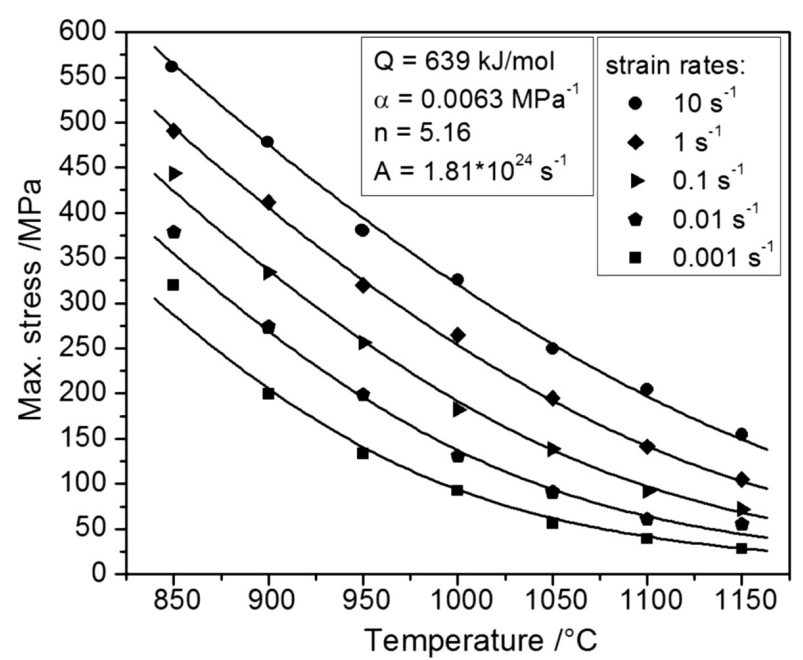

Figure 3: Comparison between measured and calculated peak values of the flow curves at different temperatures and strain rates

Slika 3: Primerjava med izmerjenimi in izračunanimi vrednostmi za maksimalne napetosti tečenja pri različnih temperaturah in hitrostih deformacije

between the measured and calculated peak stresses is given in Figure 3, where very good agreement was obtained. A slight deviation can be observed at $850{ }^{\circ} \mathrm{C}$ for the lowest strain rate, i.e., $0.001 \mathrm{~s}^{-1}$, which can be attributed to an increased precipitation of secondary carbides (Figure 4a) under these thermo-mechanical conditions. Furthermore, more intensive precipitation of the secondary carbides begins at temperatures below $1050{ }^{\circ} \mathrm{C}$, while above it precipitation was almost not observed (Figure $\mathbf{4 b}$ for the deformation temperature of $\left.1100{ }^{\circ} \mathrm{C}\right)$.

Since for both microstructural states in the deformation chain, i.e., ingot hot rolling as well as billet deformation, soakings were carried out at previous assessed appropriate temperatures, small sized carbides were expected in all the specimens deformed at $850{ }^{\circ} \mathrm{C}$. Namely, soaking at the appropriate temperature does not lead to oversized carbides. ${ }^{4}$ Soakings before the deformation of the ingot (as-cast state) were carried out at $1150{ }^{\circ} \mathrm{C}$, while for a billet (wrought state) this tempera-

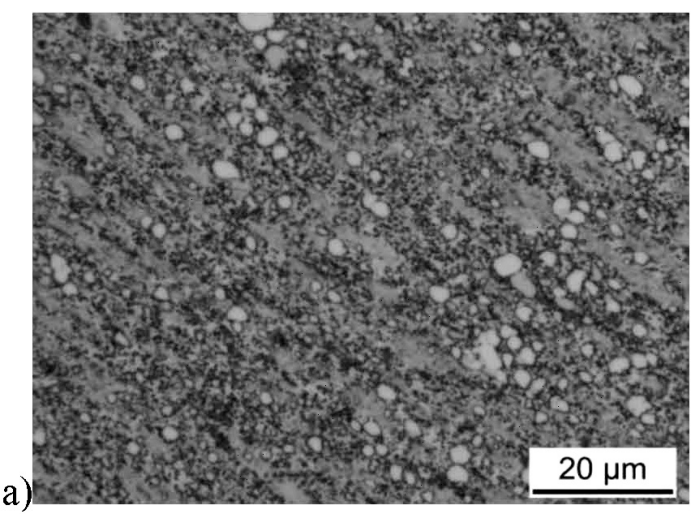

a)

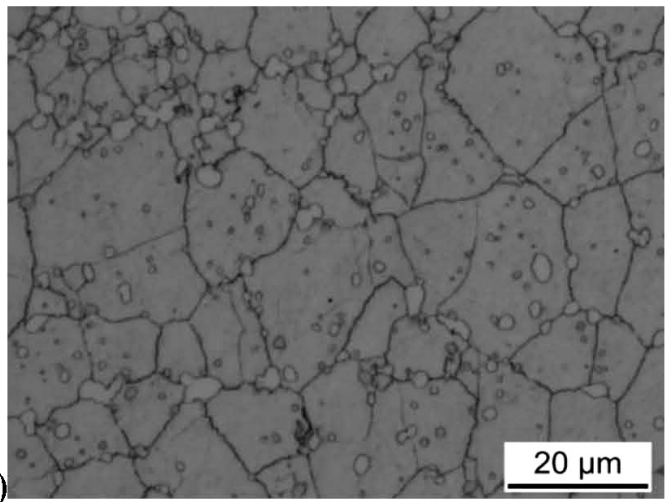

Figure 4: Precipitation of secondary carbides at lower strain rates; intensive precipitation at lower temperatures $\left(850^{\circ} \mathrm{C}\right)$ and decreased precipitation at higher temperatures $\left(1100^{\circ} \mathrm{C}\right)$

Slika 4: Izločanje sekundarnih karbidov pri nižjih hitrostih deformacije; intenzivno izločanje pri nižjih temperaturah $\left(850{ }^{\circ} \mathrm{C}\right)$ ter manj intenzivno izločanje pri višjih temperaturah $\left(1100{ }^{\circ} \mathrm{C}\right)$

ture was $1160{ }^{\circ} \mathrm{C}$. Very similar microstructures for strain rates of $0.01 \mathrm{~s}^{-1}$ and above (for strain rate of $0.01 \mathrm{~s}^{-1}$, Figure 5a) at a deformation temperature of $850{ }^{\circ} \mathrm{C}$ were obtained. From Figure 5a it can be further visible that small sized carbides are mainly below $3 \mu \mathrm{m}$, which also indicates good mechanical properties for the further application of the M35 HSS. At deformations at higher temperatures, i.e., $1050{ }^{\circ} \mathrm{C}$, slightly increased coarsening of carbides can be observed at lower strain rates (Figure 5b) in comparison to higher strain rates, i.e., $1 \mathrm{~s}^{-1}$
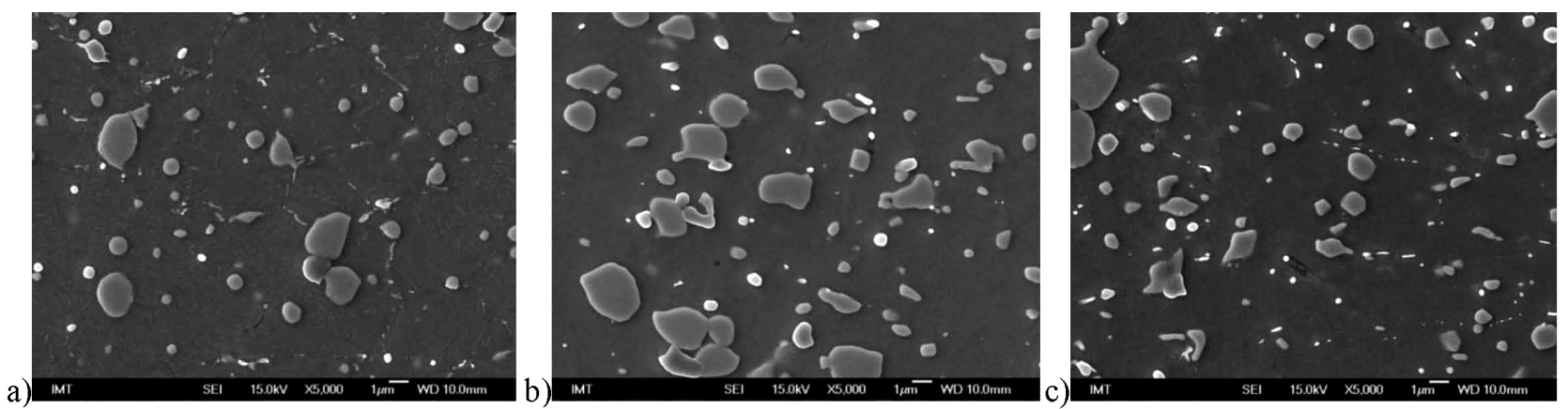

Figure 5: SEI micrographs for compressed specimens at different temperatures and strain rates: a) $850{ }^{\circ} \mathrm{C}$ and strain rate of $0.01 \mathrm{~s}^{-1}$, b) $1050{ }^{\circ} \mathrm{C}$ and strain rate of $\left.0.01 \mathrm{~s}^{-1}, \mathrm{c}\right) 1050{ }^{\circ} \mathrm{C}$ and strain rate of $1 \mathrm{~s}^{-1}$

Slika 5: SEI mikrostrukture za tlačno deformiran vzorec pri različnih temperaturah in hitrostih deformacije: a) $850{ }^{\circ} \mathrm{C}$ in hitrost deformacije $0.01 \mathrm{~s}^{-1}$, b) $1050{ }^{\circ} \mathrm{C}$ in hitrost deformacije $0.01 \mathrm{~s}^{-1}$, c) $1050{ }^{\circ} \mathrm{C}$ in hitrost deformacije $1 \mathrm{~s}^{-1}$ 
I. PERUŠ et al.: IMPROVING OF HOT WORKABILITY AND EXPANDING THE TEMPERATURE RANGE ...

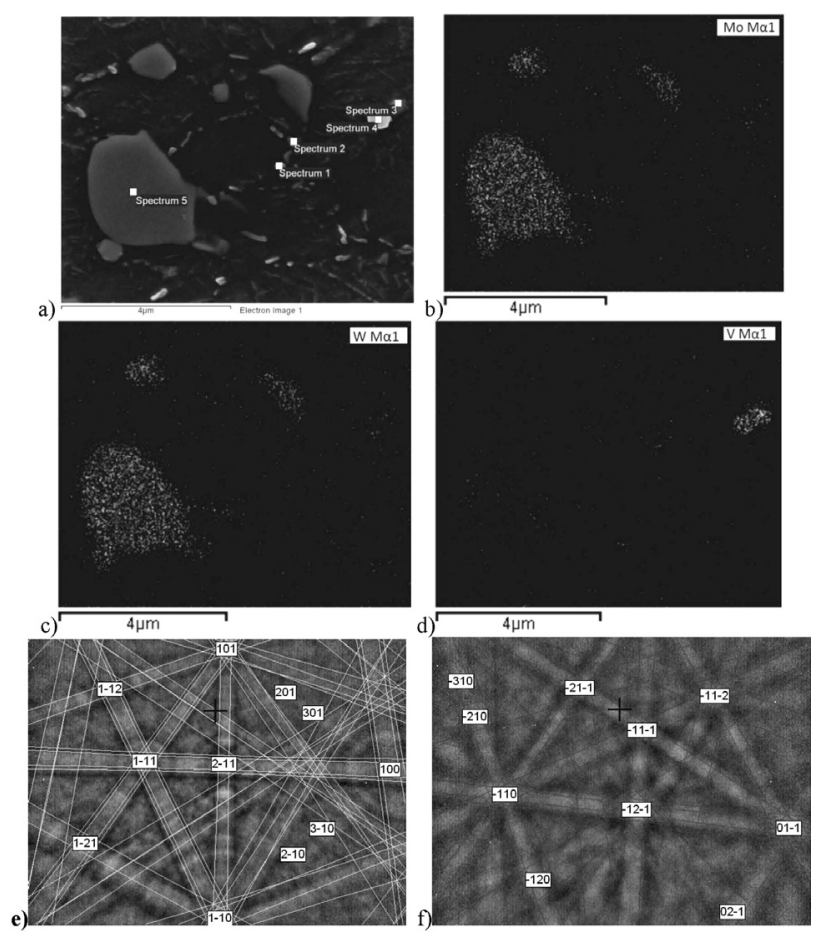

Figure 6: SEI image of carbides distribution with denoted spots for: a) chemical and EBSD analysis on deformed sample, b) distribution of Mo, c) distribution of $\mathrm{W}$ and d) distribution of $\mathrm{V}$, e) Kikuchi pattern for $\mathrm{M}_{6} \mathrm{C}$ type (spectrum 5) and for: $\mathrm{f}$ ) $\mathrm{MC}$ type of carbides (spectrum 4) deformation temperature $850{ }^{\circ} \mathrm{C}$

Slika 6: SEI slika prostorske porazdelitve karbidov z označenimi mesti za: a) kemijsko in EBSD analizo vzorcev deformiranih pri temperaturi $850{ }^{\circ} \mathrm{C}$, b) porazdelitev $\mathrm{Mo}$, c) porazdelitev $\mathrm{W}$ in d) porazdelitev V, e) Kikuchijevi vzorci za M6C tip karbidov (spekter 5) in za: f) MC tip karbidov (spekter 4)

(Figure 5c). This can be attributed to the more time that is available for an increase of their size.

For samples deformed at $850{ }^{\circ} \mathrm{C}$ the analyses of the chemical compositions of the carbides were carried out together with the determination of their types. These results are shown in Figure 6 and Table 2. Typical image of presented carbides in the matrix with denoted points for chemical analysis is shown in Figure 6a. Analysis of spectrum 5 reveals that Mo (19.2\%) and W $(36.7 \%)$ are the main elements in carbides with relative increased size that is further confirmed in Figures $6 \mathbf{b}$ to 6c, where distributions of both elements, respectively, are presented. The amount of $\mathrm{V}$ in this case is relatively low, i.e., $2.97 \%$. On the other hand, an analysis of spectrums 3 and 4 revealed that in these carbides $\mathrm{V}$, i.e.,
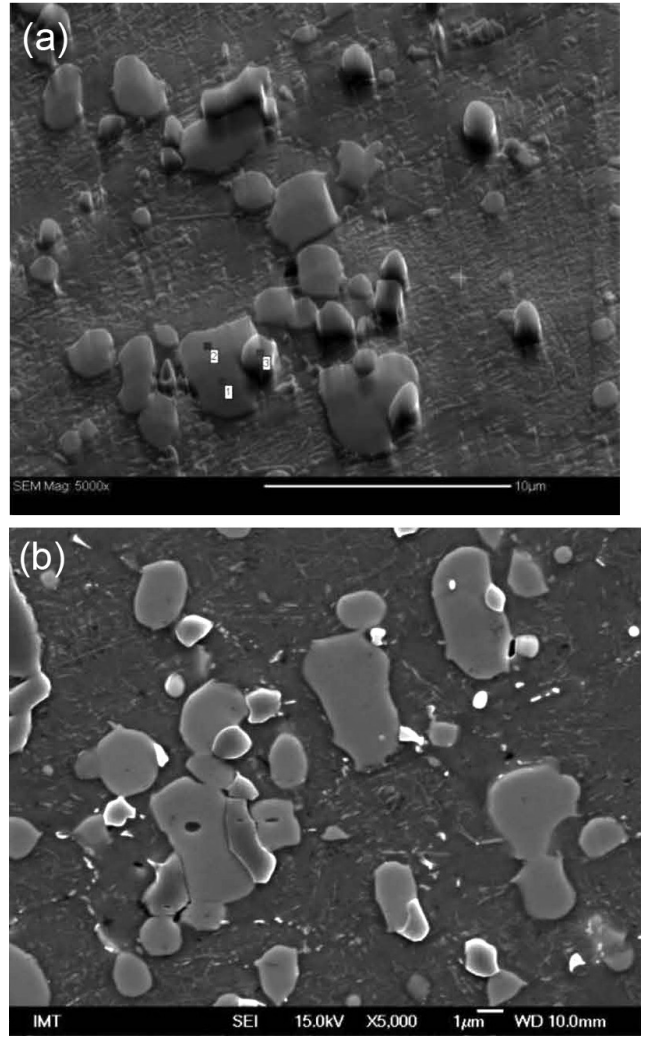

Figure 7: Coalescence of carbides of different types (a-b) Slika 7: Koalescenca različnih tipov karbidov (a-b)

$26.21 \%$ and $20.28 \%$, respectively, and Mo, i.e., 11.3 and $10.4 \%$, respectively, and $\mathrm{W}$, i.e., $14.8 \%$ and $13.7 \%$, respectively, are the most important carbide-forming elements. The distribution of $\mathrm{V}$ on these spots is given in Figure 6d. The amounts of Fe for spectrums 3 and 4 were $28.7 \%$ and $31.8 \%$, while for spectrums 1 and 2 these values were 92.9 and $67.1 \%$, respectively, but with much lower amounts of $\mathrm{V}, \mathrm{Mo}$ and $\mathrm{W}$ in comparison to spectrums 3 and 5. Thus, on spots 1-2 the amounts of these elements were 5.7 and $2.6 \%, 5.8$ and $6.4 \%$, and 7.1 and $7.4 \%$, i.e., for $\mathrm{V}$, Mo and $\mathrm{W}$, respectively. The analysis further revealed that the carbide on spectrum 5 refers to the $\mathrm{M}_{6} \mathrm{C}$ type (Kikuchi pattern given on Figure 6e), on spectrums 1, 3 and 4 to MC type (Kikuchi pattern given on Figure 6f), while on spectrum 2, this refers to the $\mathrm{M}_{23} \mathrm{C}_{6}$ type. From the distribution of the chemical elements in the carbides it can be concluded that increased sized carbides refer to $\mathrm{M}_{6} \mathrm{C}$ type. A comparison of the results related to the carbides for as-cast state

Table 2: Chemical composition in mass fractions, $(w / \%)$ on denoted spots given in Figure 5a

Tabela 2: Kemijska sestava v masnih deležih, $(w / \%)$, na označenih mestih, ki so podana na Sliki 5a

\begin{tabular}{|l|c|c|c|c|c|c|c|c|c|}
\hline & C & V & Cr & Fe & Co & Mo & W & Type & Type \\
\hline Spectrum 1 & 10.3 & 5.7 & 4.1 & 62.9 & 4.2 & 5.8 & 7.1 & $\mathrm{MC}$ & $\mathrm{VC}$ \\
\hline Spectrum 2 & 7.7 & 2.6 & 3.9 & 67.1 & 4.8 & 6.4 & 7.4 & $\mathrm{M}_{23} \mathrm{C}_{6}$ & $\mathrm{Cr}_{23} \mathrm{C}_{6}$ \\
\hline Spectrum 3 & 12.4 & 26.2 & 3.9 & 29.7 & 1.8 & 11.3 & 14.8 & $\mathrm{MC}$ & $\mathrm{VC}$ \\
\hline Spectrum 4 & 14.4 & 20.3 & 3.6 & 31.8 & 2.1 & 10.4 & 13.7 & $\mathrm{MC}$ & $\mathrm{VC}$ \\
\hline Spectrum 5 & 7.4 & 3.0 & 2.7 & 28.7 & 2.4 & 19.2 & 36.7 & $\mathrm{M}_{6} \mathrm{C}$ & $\mathrm{Fe}_{3} \mathrm{~W}_{3} \mathrm{C}$ \\
\hline
\end{tabular}




\section{PERUŠ et al.: IMPROVING OF HOT WORKABILITY AND EXPANDING THE TEMPERATURE RANGE ...}

(Figure 1 and Table 1), where $\mathrm{M}_{2} \mathrm{C}$ and $\mathrm{MC}$ types of carbides were found, with those for deformed state (Table 2), where three types of carbides, i.e. $\mathrm{M}_{6} \mathrm{C}, \mathrm{MC}$ and $\mathrm{M}_{23} \mathrm{C}_{6}$, were revealed, implies that $\mathrm{M}_{2} \mathrm{C}$ type of carbides were transformed into $\mathrm{M}_{6} \mathrm{C}$ and $\mathrm{MC}$ types. ${ }^{4}$ The occurrence of the $\mathrm{M}_{23} \mathrm{C}_{6}$ type in the wrought microstructure can be attributed to the precipitation of secondary carbides.

Here, it is worth to mention that also the coalescence (unification) of different types of carbides was observed in the sample deformed at $850{ }^{\circ} \mathrm{C}$, i.e., predominately $\mathrm{M}_{6} \mathrm{C}$ type (Figure 7a, spots 1-2) and MC type (Figure 7a, spot 3). This can be seen in Figures $7 \mathbf{a}$ to $\mathbf{b}$. Thus in the final microstructure of M35 HSS very complex carbides are presented. Industrial practice ${ }^{3}$ confirms our laboratory results that are related to improving the hot deformability, expanded range of safe hot deformation and size of carbides.

\section{CONCLUSIONS}

To increase the hot workability of M35 HSS industrial hot rolling and hot compression tests were carried out, which was supported with an analysis of the microstructure. From the obtained results the following conclusions can be derived:

- The appropriate soaking temperature depends on the initial microstructural state of M35 HSS, where for as-cast state this value is slightly lower in comparison to the wrought state, i.e., 1150 and $1160{ }^{\circ} \mathrm{C}$, respectively.

- The selection of the appropriate soaking temperature has a decisive influence on the characteristics of carbides, on the hot workability, and on expanding the temperature range for safe hot working, i.e., at its upper and lower limits. In consequence, this influences the mechanical properties of the final product. The selection of the appropriate soaking temperature for both microstructural states in process chain of hot rolling led to a decreased size of the carbides in final product, i.e., approximately $3 \mu \mathrm{m}$. Safe hot rolling up to temperatures around $850{ }^{\circ} \mathrm{C}$ is thus assured, which enable hot rolling of profiles with smaller crosssections.

- $\mathrm{M}_{2} \mathrm{C}$ and $\mathrm{MC}$ types of carbides were found in as-cast microstructure.

- $\mathrm{M}_{6} \mathrm{C}, \mathrm{MC}$ and $\mathrm{M}_{23} \mathrm{C}_{6}$ types of carbides were found in the final microstructures of compressed samples that deformed at $850{ }^{\circ} \mathrm{C}$. Carbides of type $\mathrm{M}_{6} \mathrm{C}$ as largest carbides reached a size of around $3 \mu \mathrm{m}$. W and Mo are the main carbide-forming elements in these types of carbides. Smaller-sized carbides refer to the MC type where $\mathrm{V}$ is the main carbide-forming element.

- Unification of different types of carbides takes place, i.e., predominately $\mathrm{M}_{6} \mathrm{C}$ and $\mathrm{MC}$, which results in very complex compositions of carbides.
- The calculated apparent activation energy for hot working amounts to $639 \mathrm{~kJ} / \mathrm{mol}$.

\section{REFERENCES}

${ }^{1}$ J. Liu, H. Chang, R. Wu, T.Y. Hsu, X. Ruan, Investigation on hot deformation behaviour of AISI T1 high-speed steel, Materials Characterization, 45 (2000), 175-186, doi:10.1016/S1044-5803(00) 00071-1

${ }^{2}$ C. A. C. Imbert, H. J. McQueen, Hot ductility of tool steels, Canadian Metallurgical Quarterly, 40 (2001), 235-244, doi:10.1179/ 000844301794388461

${ }^{3}$ T. Večko Pirtovšek, G. Kugler, M. Godec, M. Terčelj, Three important points that relate to improving the hot workability of ledeburitic tool steels, Metallurgical and Materials Transactions A, 43 (2012) 10, 3797-808, doi:10.1007/s11661-012-1195-4

${ }^{4}$ T. Večko Pirtovšek, G. Kugler, M. Godec, M. Terčelj, Microstructural characterization during the hot deformation of $1.17 \mathrm{C}-11.3 \mathrm{Cr}$ 1.48V-2.24W-1.35Mo ledeburitic tool steel, Materials Characterization, 62 (2011) 2, 189-197, doi:10.1016/j.matchar.2010.11.016

${ }^{5}$ T. Pepelnjak, B. Barišič, Analysis and elimination of the stretcher strains on TH415 tinplate rings in the stamping process, Journal of Materials Processing Technology,186 (2007), 111-119, doi:10.1016/ j.jmatprotec.2006.12.025

${ }^{6}$ D. Klobčar, J. Tušek, B. Taljat, Thermal fatigue of materials for die-casting tooling, Materials Science and Engineering A, 472 (2008), 198-207, doi:10.1016/j.msea.2007.03.025

${ }^{7}$ J. Rech, P. J. Arrazola, C. Claudin, C. Courbon, F. Pusavec, J. Kopac, Characterisation of friction and heat partition coefficients at the tool-work material interface in cutting, CIRP Annals - Manufacturing Technology, 62 (2013) 1, 79-82, doi:10.1016/j.cirp.2013. 03.099

${ }^{8}$ F. Yan, H. Shi, B. Jin, J. Fan, Z. Xu, Microstructure evolution during hot rolling and heat treatment of the spray formed Vanadis 4 cold work steel, Materials Characterization, 59 (2008), 1007-1014, doi:10.1016/j.matchar.2007.08.012

${ }^{9}$ T. Večko Pirtovšek, G. Kugler, M. Terčelj, The behaviour of the carbides of ledeburitic AISI D2 tool steel during multiple hot deformation cycles, Materials Characterization, 83 (2013), 97-108, doi:10.1016/j.matchar.2013.06.008

${ }^{10}$ R. Milovic, D. Manojlovic, M. Andjelic and D. Drobnjak, Hot workability of M2 type High-speed steel, Steel Research, 63 (1992), 78-84

${ }^{11}$ C. Rodenburg, M. Kryzanowski, J. H. Beynon, W. M. Rainforth, Hot workability of spray-formed AISI M3:2 high speed steel, Materials Science and Engineering A, 386 (2004), 420-427, doi:10.1016/ j.msea.2004.07.056

${ }^{12}$ Z. Bin, S. Yu, C. Yun, C. Zhen-shan, Breakdown Behavior of Eutectic carbide in High Speed Steel During Hot compression, Journal of Iron and Steel Research, International, 18 (2011)1, 41-48, doi:10.1016/S1006-706X(11)60009-5

${ }^{13}$ A. Akbarzadeh, S. Naghdy, Hot workability of a high carbon high chromium tool steel, Materials \& Design, 46 (2013), 654-659, doi:10.1016/j.matdes.2012.10.055

${ }^{14}$ H. Kim, J. Y. Kang, D. Son, T. H. Lee, K. M. Cho, Evolution of carbides in cold-work tool steels, Materials Characterization, 107 (2015), 376-385, doi:10.1016/j.matchar.2015.08.001

${ }^{15}$ M. R. Ghomashchi, C. M. Sellars, Microstructural Changes in As-cast M2 Grade High Speed Steel during Hot Forging, Metallurgical Transactions A, 24A (1993) 2171-2179, doi:10.1007/ BF02648591

${ }^{16}$ J. Gontarev, M. Doberšek, J. Medved, P. Mrvar, Solidification of hipereutectoid high speed steel for rolls, Metalurgija 50 (2011) 1, 29-32

${ }^{17}$ W.Shizhong, Z. Jinhua, X. Liujie, L. Rui, Effects of carbon on microstructures and properties of high vanadium high-speed steel, Materials and Design, 27 (2006), 58-63, doi:10.1016/j.matdes. 2004.09.027 


\section{MATERIALI IN TEHNOLOGIJE/MATERIALS AND TECHNOLOGY (1967-2017) - 50 LET/50 YEARS}

\section{PERUŠ et al.: IMPROVING OF HOT WORKABILITY AND EXPANDING THE TEMPERATURE RANGE ...}

${ }^{18}$ M. A. Hidzadameh, M. Meratian, A. Saatchi, Effect of cerium and lanthanum on the microstructure and mechanical properties of AISID2 tool steel, Materials Science \& Engineering A, 571 (2013), 193-198, doi:10.1016/j.msea.2013.01.074

${ }^{19}$ K. C. Hwang, S. Lee, H. C. Lee, Effect of alloying elements on microstructure and fracture properties of cast high speed steel rolls, Part I: Microstructural analysis, Materials Science and Engineering A, 254 (1998), 282-295, doi:10.1016/S0921-5093(98)00626-1

${ }^{20}$ V. Vitry, S. Nardone, J. P. Breyer, M. Sinnaeve, F. Delaunois, Microstructure of two centrifugal cast high speed steels for hot strip mills applications, Materials and Design, 34 (2012), 372-378, doi:10.1016/j.matdes.2011.07.041

${ }^{21}$ H. Di, X. Zhang, G. Wang, X. Liu, Spheroidizing kinetics of eutectic carbide in the twin roll-casting of M2 high speed steel, Journal of Materials Processing Technology, 166 (2005), 359-363, doi:10.1016/ j.jmatprotec.2004.07.085
${ }^{22}$ M. R. Ghomashchi: Quantitative microstructural analysys of M2 grade high speed steel during high temperature treatment, Acta Materialia, 46 (1998) 14, 5207-5220, doi:10.1016/S1359-6454(98) 00110-4

${ }^{23}$ P. Ding, G. Shi, S. Zhou, As-cast Carbides in High-Speed Steels, Metallurgical Transactions A, 24 (1993), 1265-1271, doi:10.1007/ BF02668195

${ }^{24}$ T. Inoue, F. Yin, Y. Kimura, Strain Distribution and microstructural evaluation in multi-pass warm calibre rolling, Materials Sciences and Engineering A, 466 (2007) 1-2, 114-122, doi:10.1016/j.msea.2007. 02.098

${ }^{25}$ J. J. Jonas, C. M. Sellars, W. J. M. Tegart, Strength and structure under hot working conditions, Metall. Rev., 130 (1969), 1-24, doi:10.1179/mtlr.1969.14.1.1

${ }^{26}$ G. Kugler, M. Knap, H. Palkowski, R. Turk, Estimation of activation energy for calculating the hot workability properties of metals, Metalurgija, 43 (2004) 4, 267-272 